\title{
JuRISDiCTIONAL CONTROL IN THE SPHERE of Public Health Protection in the RUSSIAN FEDERATION
}

Accepted

23. 02. 2020

Revised

29. 08. 2020

Published

29. 10. 2020

Keywords

medical

law,

health

protection,

mandatory

judicial

control,

medical

legislation,

administrative

proceedings.

\author{
SERgEy Victorovich Potapenko \& \\ EVGENIY BORISOVICH LUPAREV \\ Kuban State University, Faculty of Law, Krasnodar, Russian Federation. \\ E-mail: potapenkosv@yandex.ru, jeklouparev@yandex.ru \\ CORRESPONDING AUTHOR \\ potapenkosv@yandex.ru
}




\section{$1 \quad$ Introduction}

The relevance of the declared issues is largely due to the sharp increase in the number of claims in the courts of the Russian Federation regarding the need to respect the rights and legitimate interests of patients who receive involuntary medical care. Many conflict situations require a logical system of medical legislation in order for the law enforcer to clearly understand the limits of the requirements for medical workers and patient's legal claims to exclude the so-called "medical malpractice" (Spakovsky \& Park, 2011: 3).

The issue of administrative legal disputes in the field of medical activity lies in the general context of disputes and is characterized by the specifics of the object and subject of the legal dispute.

The composition of subjects of an administrative legal dispute related to medical activity assumes a mandatory subject endowed with state powers in the field of medical activity. These may include not only state or municipal bodies but also medical organizations that are endowed with certain governmental functions.

Any organizations, including medical ones, as well as persons against whom the provisions of the Code of Administrative Judicial Procedure (CAJP) of the Russian Federation are applied, or persons who are the subject of relations regulated by the contested administrative act, can be the subjects of administrative judicial dispute in the field of medical activity if they believe that this act was violated or may violate their rights, freedoms and legitimate interests.

Since both sanitary and epidemiological well-being comprise integral components of health protection, their contestation in the regulatory acts within the provisions of Art. 2 of the Federal Law "On Health Protection of Citizens of the Russian Federation" demonstrates that the legislature considers both components as medical. It is important to remember that the determination of sanitary norms and rules may fall within the competence of specialized state bodies only, whereas the regulation of other issues related to the implementation of these norms may fall within the competence of state governments in the Russian Federation. Because of the excessive state powers in the Russian Federation, defined by federal acts on 
protection, there arise administrative legal disputes, in particular, with regard to the capture of stray animals.

While cases pertaining to the contestation of regulatory legal acts may not be directly related to the protection of public health, they are nevertheless important as they relate to the features of the tax status of medical organizations.

Administrative legal disputes related to the commission or refusal of certain actions by medical organizations and their officials are regulated by Chapter 22 of the Code of Administrative Judicial Procedure of the Russian Federation (hereinafter CAJP). However, the authors maintain that a differentiated approach is required to classify medical cases as administrative legal disputes. Our rationale for this contention has as its underpinnings the subject composition of the disputing parties and the object of the dispute. Specifically, it is important to understand whether a medical organization or its official is endowed with governmental or other public powers. Thus, the Supreme Court of the Russian Federation in the cassation ruling in the case No. 34-КГ16-12 dated November 2, 2016, drew the attention of lower courts to the fact that the head of the medical unit of the Federal Penitentiary Service is authorized, and exercises administrative and other governmental powers over the implementation and application of laws in the field of health care in respect of persons detained in pre-trial detention centres. These arguments are important from the point of view of determining the subject area of the study, with respect to which we characterize the mandatory judicial control over the medical activity.

\section{Theoretical, informational, empirical and methodological bases of the study}

\subsection{Administrative-judicial and administrative-tort control}

In the context of the application of Chapter 22 of the CAJP to the field of medicine, complexities arise in cases where non-governmental organizations act as an administrative defendant. In each particular case, the law enforcer has to ascertain, guided by the rules determining the status of an organization, whether that organization has governmental or other public powers. The nature of such powers is not always the same. In a particular case of Yevgeniy Alekseyenko v. Russia, 27/04/2011, the Supreme Court of Russia indicated that anti-tuberculosis medical 
organizations are vested with separate public powers in terms of imposing on them the obligation to inform the bodies carrying out federal state sanitary and epidemiological supervision.

However, there is still the question of how best to handle officials of medical organizations, whose actions and inactions can be challenged under the administrative procedure. It is not the employees of medical organizations, whose status as "officials" is not in doubt (e.g., chief physician, senior nurse, department head) but rather the physicians themselves who actually cause the problem. Due to the lack of a universal legal definition of an official, there is little alternative but to use this concept by analogy, taking the corresponding wording from the note to Art. 2.4 of the Administrative Offences Code of the Russian Federation (Suchkova, 2012: 142-145).

The authors contend that in some cases a physician performs dual roles by not only providing professional medical services but also carrying out the organizational and administrative functions of an official. For example, if there is an issue of refusal to issue a temporary disability certificate, make a medical record, recognize a person's disability by a physician employed in the bureau of medical and social expertise and, accordingly, only in these and similar cases that create legally significant consequences of a public nature, the physician's actions and/or inactions can be challenged following Chapter 22 of the CAJP.

A separate group of administrative cases in the field of medical activity considered following the CAJP:

- on mandatory (involuntary) hospitalization in an anti-tuberculosis medical organization;

- on the hospitalization of a citizen in a medical organization that provides psychiatric care in an inpatient setting, in an involuntary manner, on the extension of the term for hospitalization of a citizen in an involuntary manner, or on the psychiatric examination of a citizen in an involuntary manner;

- on the protection of interests of a minor or a person declared legally incapable in the event of a legal representative's refusal of medical intervention necessary to save a life (Burashnikova, 2018: 7-11); 
- other administrative cases on hospitalization of a citizen in a non-psychiatric medical organization in an involuntary manner (Wendelboe, Avery \& Andrade, 2011: 990).

The last of these cases essentially allows referring to the actual grounds of administrative judicial control over diseases that represent not only individual harm but can also become a source of mass infections, which entails adverse social consequences for an indefinite number of people.

However, the the administrative legal dispute in this category of cases is subject to the provisions of the CAJP only when the person against whom the case is being considered refuses to voluntarily undergo treatment in the relevant medical organization, challenges the need for such treatment, or otherwise disputes the violation of the relevant sanitary rules directly in court.

The grounds for involuntary hospitalization of a citizen in a medical organization that provides psychiatric care in an inpatient setting differ from the grounds for declaring a person incapable. The medical question to be determined in court in accordance with Clause 1, Part 1, Art. 278 of the CAJP is whether the person suffers from a "severe mental disorder". Unfortunately, the current legislation does not clearly articulate what actually constitutes a severe mental disorder. It is clear that "diseases such as alcoholism, drug addiction and substance abuse themselves are not severe mental disorders and cannot serve as a basis for involuntary hospitalization ${ }^{1 "}$. However, this is the case only up to a certain stage of the disease and in fact constitutes one of the grounds for involuntary hospitalization if the conduct of such patients is associated with the circumstances described in Art. 29 of the Federal Law "On Psychiatric Care and Guarantees of the Citizens' Rights in the Course of Care Provision" and Clause 2, Part 1, Art. 278 of the CAJP. A comparative analysis of the provisions of Art. 29 of the Federal Law "On Psychiatric Care and Guarantees of the Citizens' Rights in the Course of Care Provision" and Art. 278 of the CAJP reveals the conflicting nature of the terminology used. In this article we first discuss mental disorders and then severe mental disorders. The use of terminology inconsistent with the CAJP in procedural documents may serve as a formal basis for refusal in an administrative claim.

\footnotetext{
${ }^{1}$ Clause 1, Part 1, Art. 278 of the CAJP.
} 
The virulent form of tuberculosis is the medical ground for initiating a case of involuntary hospitalization in an anti-tuberculosis medical organization. The actual material and legal grounds are as follows:

1. repeated (that is, two or more times) violation of sanitary and anti-epidemic regime for patients with virulent forms of tuberculosis;

2. deliberate evasion of tuberculosis treatment.

However, the structure of Part 1, Art. 281 of the CAJP involves involuntary hospitalization in an anti-tuberculosis medical organization in case of deliberate evasion of the examination for suspected tuberculosis. In other words, involuntary hospitalization is possible where there are sufficient grounds to believe a person has any form of tuberculosis, including virulent forms under the condition of deliberate evasion of examination as supported by opinions of the experts involved in the case (Kulakov, 2017: 21).

The sanitary and epidemiological regime of patients with virulent forms of tuberculosis poses strict requirement that the patient, in accordance with Art. 13 of the Federal Law dated 18.06.2001 No. 77-FZ (edition dated 03.08.2018) "On Prevention of TB Spread in the Russian Federation" and Clause 1.3 of the Resolution of the Chief State Sanitary Physician of the Russian Federation dated 22.10.2013 No. 60 (edition dated 06.02.2015) "On Approval of Sanitary and Epidemiological Rules SP 3.1.2.3114-13 'TB Prevention' (with 'SP 3.1.2.3114-13...')", shall comply with the relevant rules, as follows: undergo examination, controlled treatment and comply with hygiene standards for interaction with others.

In this regard, we consider that the wording of Art. 281 of the CAJP2, which states that not only a person who deliberately evades treatment or examination, that is, his or her actions which challenge regulations of the authorized organization, but also a person who violates the sanitary and anti-epidemic regime, is unclear. In the situation where a person violates the sanitary and anti-epidemic regime, about the focus in not about a dispute but rather the application of administrative and coercive

\footnotetext{
${ }^{2}$ Art. 281 of the CAJP says the following: "1. An administrative statement of claim for the involuntary hospitalisation of a citizen to a medical antituberculous organisation may be submitted in regard of a citizen infected with a contagious form of tuberculosis, who has repeatedly violated the sanitary-anti-epidemic regime, or in regard of a citizen, who intentionally evades examination aimed at detection of tuberculosis or tuberculosis treatment" (http://www.supcourt.ru/en/files/16401/ - Accessed 9 October 2020).
} 
measures by the court to the offending person (Lebedeva, 2015: 204). Moreover, the above-mentioned Sanitary and Epidemiological Rules SP 3.1.2.3114-13 "TB Prevention" do not contain specific regulations designed for a person with tuberculosis. The rules of this regulatory act refer only to public bodies and medical organizations but not to the patient, which corroborates the need to clarify the provisions of Art. 13 of the Federal Law dated 18. 06. 2001 № 77-FZ (edition dated 03.08.2018) "On Prevention of TB Spread in the Russian Federation" with specific obligations to comply with the sanitary and anti-epidemic regime for tuberculosis patients.

The coronavirus pandemic (COVID-19) and related organizational and legal issues in the sphere of medicine stem from more general issues, namely, the prompt legislative regulation of medical administrative responsibility and involuntary hospitalization. Currently, the legislator proposes the name of Chapter 6 of the Code of Administrative Offences of the Russian Federation as a generic object, namely, "Administrative offenses that infringe on the health, sanitary and epidemiological welfare of the population and public morality". Certainly, in this case the legislator combined in the generic object of administrative offences the delicti of sometimes quite heterogeneous properties.

Practice has demonstrated that the basis of the Administrative-delicti prevention of the spread of COVID-19 became Art.icle 6.3 of the Administrative Code of the Russian Federation, which is a special norm in relation to Art. $20.6^{1}$ of the Administrative Code, the application of which the Supreme Court has devoted a special "Review on certain issues of judicial practice related to the application of laws and measures for counter-proliferation in the Russian Federation of a new coronavirus infection (COVID-19)" \# 1 dated April 21, 2020. ${ }^{3}$ It is noteworthy that during the pandemic, the Supreme Court allowed the application of regulations of the federal law on administrative responsibility for violation of rules and norms established by laws of constituent entities of the Russian Federation, while outside of high alert conditions, such a practice was not allowed.

\footnotetext{
${ }^{3}$ https://www.vsrf.ru/files/28856/ (accessed at 26.04.2020).
} 
Within the context of our research it is important to distinguish between health protection, sanitary and epidemiological well-being on the one hand and medical activity itself on the other hand. Due to the fact that we are largely interested in the problem of systematization of medical legislation, it is critical to comprehend where medical activities end and where they start. Additionally, it is paramount that we understand which activities, although clearly affecting the public's health, nevertheless are not actually medical. Contemporary works in medical law theory attempt to distinguish between concepts such as "medical care" and "medical service" (Ponomarev, 2018: 30-35). Nevertheless, the fundamental importance in the field of public legal sphere of legal regulation uses the terminology "medical activity" as stipulated at p. 10, Art. 10 of the federal law dated November, 21, 2011 (ed. at March, 6, 2019) "On health protection of Russian citizens"4 and "health care of citizens" stipulated at p. 2 of Ponomarev's article. Evidently, "medical activity" is a constituent element of citizens' health care, meaning that these terms correlate as general and singular and are subordinated. At the same time, the interpretation of Art. 2 of the federal law "On the protection of the health of citizens of the Russian Federation" suggests that the legislator considers measures of a sanitary and epidemiological (preventive) nature as constituting medical ones. ${ }^{5}$ Taking into account the provision on the preventive aspect of health care, it is possible to outline several formulations of Art. 14 of the Administrative Code of the Russian Federation "Administrative offences in the sphere of entrepreneurship activities and selfregulatory bodies activities" which relate to prevention of diseases: 14.1 Implementation of entrepreneurship activities without state registration or without special permit (license) - in case medical activity is implied ${ }^{6} ; 14.2$ Illegal sale of goods (other items) free sale of which is prohibited or restricted ${ }^{7}$ by part 5 of Art. 14.3 Violation of requirements laid down by legislation related to advertising of medicines, medical items and medical services including the means of treatment and biologically active additives; 14.3.1 Sponsorship and promotion of tobacco, tobacco products and/or tobacco consumption or tobacco and tobacco products advertising

\footnotetext{
${ }^{4}$ http:/ / www.pravo.gov.ru - 22.11.2011 (6 March 2019).

${ }^{5}$ See for example: On the need to license the provision of disinfection services if this service is not provided within the framework of medical care: Letter of the Ministry of health of the Russian Federation dated 13.05.2014 No. 241-2036856 / Not published officially ATP "Consultant plus", date accessed - 20 March 2019.

${ }^{6}$ See for example: Resolution of the FAS of the North Caucasus district dated at 28.12.2009 judgement in case no. A53-12748/2009/ SPS "Consultant plus", date of address - 03 .04. 2019.

${ }^{7}$ In particular, in accordance with part 2 of Art. 18 of Federal law No. 125-FZ of 20.07.2012 (ed. at 07.03.2018) "On blood donation and its components" restricted the sale of donated blood and its components received in the Russian Federation to other States - http://www.pravo.gov.ru date of address 23 July 2012.
} 
or smoking accessories; 14.4.2 Violation of the legislation on circulation of medicines; 14.18 Use of ethanol produced from non-food raw materials, alcoholcontaining non-food products, pharmaceutical substance ethyl alcohol (ethanol) for the production of alcoholic and alcohol-containing food products; part 2 of Art. 14.43 Violation by a manufacturer, contractor (the person performing the functions of a foreign manufacturer), or the seller of requirements of technical regulations, which caused harm to the life or health of citizens.

In order to overcome the problems of modern state management of public health protection, Glushchenko proposes to introduce administrative responsibility for the following offenses:

- for the employer's refusal to provide employees with guarantees during medical examinations;

- for obstructing the lawful activities of the public Commission for quality control and safety of medical activities;

- for violating the rights and legitimate interests of citizens, medical institutions or health professionals in the implementation of quality control and safety of medical activities (Glushchenko, 2016: 13).

In turn, Mustafina-Bredikhina suggests a proposal to supplement the Administrative Code of Russia with Art. 6.34 "Violation of mandatory requirements for medical care quality (Mustafina-Bredikhina, 2018:13).

The allocation in administrative-tort legislation corpus of administrative offences that have a "medical-preventive" character is envisaged by the consideration that it is more cost effective to prevent a disease in the first place than it is to treat the disease. According to Deputy Minister of Health of the Russian Federation O. Salagay, in his announcement delivered at the Krasnoyarsk economic forum on March 30, 2019, the annual damage from non-communicable diseases only to the Russian Federation's economy is estimated at 3 trillion rubles. ${ }^{8}$ Research conducted at The National Research Center for Preventive Medicine by Kontseva, Drapkina, Balanova, Imayeva, Suvorova \& Khudyakova resulted in the conclusion that the

\footnotetext{
8 The Ministry of Health calculated the annual economic damage from non-communicable diseases https://tass.ru/ekonomika/ 6277265
} 
economic damage resulting solely from cardiovascular diseases amounts to 2.7 trillion rubles, that is, $3.2 \%$ of GDP as of 2016 (Kontsevaya et al., 2018: 156). The above-mentioned figures adjusted for calculation methods might be considered correct. Foreign authors who have studied the economic consequences of noncommunicable diseases and injuries in the Russian Federation also indicate a figure in the range of 3.6-4.8\% decrease of Russia's GDP as of 2012 (Suhrcke et al., 2018: 4).

Estimated losses to the Russian economy from infectious diseases according to statistics from the Federal Service for Supervision of Consumer Rights Protection and Human Welfare amounted to approximately 468 billion rubles in $2015^{\circ}$, which is significantly less than economic losses from non-communicable diseases. In addition, according to the same Federal Service (Rospotrebnadzor), there is a dynamic of reducing the quantitative indicators of the main mass of infectious diseases in 2017-201810, which in our opinion substantiates the effectiveness of prevention measures. However, this dynamic is not static, as evidenced by data revealing an increase in the incidence of measles by a factor of 18 in 2017-2018. ${ }^{11}$

We assume that it is difficult to achieve any significant decrease in the quantity of non-communicable diseases through the means of public administration, particularly through the channels of administrative enforcement, which includes administrative responsibility. However, the public-law prevention mechanisms do help ensure better controls over the origin and spread of infectious diseases.

A significant part of Art. 6 of the Administrative Code is aimed at preventing infectious diseases:

- Art. 6.1 - Concealment of the source of infection with HIV infection, venereal disease and contacts that cause a risk of infection;

\footnotetext{
${ }^{9}$ https://iz.ru/news/587959

${ }^{10}$ See: Infectious diseases in the Russian Federation for January-December 2018 -

https://rospotrebnadzor.ru/activities/statistical-materials/statictic_details.php?ELEMENT_ID=11277;

Infectious diseases in the Russian Federation for January-December 2017 -

https://rospotrebnadzor.ru/activities/statistical-materials/statictic_details.php?ELEMENT_ID=10049

${ }^{11}$ Data on infectious and parasitic diseases for January - May 2018 -

https://rospotrebnadzor.ru/activities/statistical-materials/statictic_details.php?ELEMENT_ID=10418
} 
- Art. 6.3 - Violation of legislation in the sphere of sanitary and epidemiological welfare of the population;

- Art. 6.4 - Violation of sanitary and epidemiological requirements for the operation of residential and public premises, buildings, structures and transport;

- Art. 6.5 - Violation of sanitary and epidemiological requirements for drinking water;

- Art. 6.6 - Violation of sanitary and epidemiological requirements for catering.

The priority of administrative and tort infectious diseases prevention is premised on the fact that infectious diseases actively spread, which means that they cause massive negative social consequences. It is enough to recall the epidemics of deadly infectious diseases that took place in the relatively recent past, such as SARS and HIV/AIDS.

The Russian legislator has not ignored the task of implementing procedures to help protect the health of citizens against non-communicable diseases set out in Art. 1.2 of the Administrative Code. The specifics of prevention of non-communicable diseases are related to the fact that they do not have the potential for large-scale distribution, but rather are individualized. However, the occurrence of certain diseases might be affected by some intrusive factors such as smoking in public areas, illegal drug trafficking, and similar factors that are subject to public administration. If we try to structure such corpus of the Administrative Code, then the preventable factors include the following: smoking; trafficking and consumption of narcotic and psychotropic substances; alcohol use; doping by athletes; information that can harm the health of minors; delivery of falsified medicines and biologically active additives; and, distribution of medical products.

From the point of view of systematization of legislation in the field of medicine, the question arises about the need for the restructuring of Chapter 6 of the Administrative Code by adding a specialized corpus in Chapter 14 with reference to the constituent elements of the corpus, for example - "Implementation of medical entrepreneurial activities without a special permit or license." 
The current version of the Administrative Code contains 88 references to the term "health" in different forms. However, this does not mean that in all cases the generic object of an illegal act is human health. For example, consider Art. 2 of the federal law dated at November 21, 2011 N 323-FZ "About bases of health protection of citizens in the Russian Federation"12 that stipulates the concept of health as "a state of physical, mental and social well-being of a person, in which any diseases and disorders of functions of organs and systems of the body are absent."

The keywords in this definition are human well-being, the absence of diseases, and related disorders. The common trait in each of these phrases is quality of life. This implies that a person's overall health depends upon a variety of factors, both physical and non-physical. Therefore, the right to life and health is usually attributed to one group of personal non-property rights providing physical well-being and human existence. It is obvious, however, that the legislator prescribed the concept of health concerning the average person in the community, as opposed to the health of any individual person in the community.

At the same time, it should be noted that the above provision of the federal law defines the right to health mainly within the framework of a biomedical approach to health and healthcare. However, the right to health is also closely linked to the right to a friendly and healthy environment for all of us.

Examining the concept of health even more broadly, it is clear that science and medicine are not the sole drivers of good health. They are unquestionably critical for the development, implementation and improvement of health care. Pharmaceuticals, vaccines and medical supplies as well are crucially important. While professional medical and nursing services play a very key function in the health care system, and toward contributing to the overall public health, it is critical not to overlook the important contribution of other activities as well.. For example, also crucial to public health are advocacy and prevention activities that focus on educating the public to make changes to avoid, if not eliminate, major health risks, such as dieting, smoking, alcohol consumption, drug use, and physical activity. These interventions are not the product of medicine or health systems. Rather, they are driven by law. In this case, the law is regarded as one of the miracle medicines, contributing to global health as

12 Collection of Legislation of the Russian Federation (CLRF), 2011, no. 48. Art. 6724 CLRF, 2011 No 48. Art. 6724 . 
ever-increasing indicators of good health and increased life expectancy in all countries of the world (Gostin, 2019: 3).

Yaroshenko outlined the non-material nature of health and considered it mainly in the context of one of the personal non-property rights of an individual (Yaroshenko, 1990: 26).

Maleina assumes that "health as an intangible good is a physical and mental state of a person, as well as well-being is the absence of diseases or pathology (trouble) associated with loss or disorder of the mental, physiological, anatomical structure and (or) functions of the human body" (Maleina, 2014: 17).

Indicative in this context are some of the provisions of Chapter 8 of the Administrative Code, which as a direct object along with environmental protection have, for example, stipulated in Art. 8.2, sanitary and epidemiological well-being, which directly affects the state of human health. However, we offer in the development of a promising new Administrative Code, ${ }^{13}$ to change the very concept of the formation of the chapter on offences in the sphere of health protection, including the maximum number of corpora that are directly related to health, even containing optional or other direct object of an administrative offence. This approach is explained by the fact that the health of citizens, even from the point of view protected by the legislation on administrative offenses, is the highest priority after the protection of personality, protection of rights and freedoms in Art. 1.2 of the current Administrative Code.

The issue of forced (involuntary) hospitalization deserves special attention. The issue of respect for the rights and legitimate interests of citizens is vitally important. This issue has taken on particular importance with respect to cases involving involuntary hospitalizations related to suspected coronavirus. Based on this, taking into account that the coronavirus infection $(2019-\mathrm{nCoV})$ is classified as a disease that is dangerous to others, medical intervention is allowed for citizens suffering from this disease without their consent. However, this only applies to individuals who have been diagnosed as B 34.2 "Coronavirus infection (2019-nCoV)" in accordance with ICD

\footnotetext{
13 Medvedev instructed to submit the concept of a new Administrative Code by June the 1st - https:/ / yandex.ru/turbo?text=https $\% 3 \mathrm{~A} \% 2 \mathrm{~F} \% 2 \mathrm{Frg} . r u \% 2 \mathrm{~F} 2019 \% 2 \mathrm{~F} 03 \% 2 \mathrm{~F} 23 \% 2 \mathrm{Fmedvedev}$-poruchilpredstavit-koncepciiu-novogo-koap-k-1-iiunia.html\&d=1
} 
- 10. In accordance with p. 3 of Part 1 of Art. 274 of the Code of Administrative Procedure (CAP) of Russia, other administrative proceedings concerning the admission of a citizen in a medical organization having a non-psychiatric profile, providing medical care in stationary conditions, involuntarily is illegal. Another case is if the legislation provides a judicial procedure for the consideration of the relevant requirements considered by the court according to the rules of Chapter 30 of the Code of Administrative offences of the Russian Federation. It is important to prove whether the person is a danger to the public.

The last of these cases in fact facilitates reference to the actual grounds of administrative and judicial control of diseases that not only cause individual harm, but also can become a source of massive infections, and which therefore can be the genesis of adverse social consequences for an indefinite circle of people.

Strictly speaking, an administrative-legal dispute in this category of cases can only be considered if the person with respect to whom the case is being considered refuses to voluntarily undergo treatment in the relevant medical organization, challenges the need for such treatment, or disputes the violation of the relevant sanitary rules directly in court.

\subsection{Differentiation of administrative-legal and criminal-legal control in the sphere of medical activity}

For the purposes of administrative and judicial control in the field of medical activity in the Russian Federation, it is important to differentiate between issues of administrative control and administrative responsibility on the one hand from issues of criminal control and criminal responsibility in the field of medicine on the other hand.

The issue of related elements of crimes and administrative offenses in the field of medical activity arises from a more general problem, namely, the problem of determining the generic object of such crimes and administrative offenses. While solving this problem, we achieve the purpose of identifying the object of unlawful infringement, taking into account factors that directly affect the health of the citizens, and objects in chapters of the Criminal Code and Administrative Code, not directly related to medical activities. Currently, the legislator proposes the name of 
Chapter 6 of the Administrative Code as a generic object, namely, sanitary and epidemiological welfare and health. In this instance, the legislator combined in the administrative offenses the generic object of delicti of sometimes quite heterogeneous properties. After all, an infringement on public morality is not always directly related to health, sanitary and epidemiological well-being, although we certainly cannot deny this link. Of course, prostitution, for example, creates a threat of spreading venereal diseases in addition to a dysfunctional social background, but there is no direct connection in this case.

Comparative analysis of the formulations of Chapter 16 of the Criminal Code and Chapters 6 and 14 of the Administrative Code leads to seemingly simple issues should compositions of these Codes be considered related? Only those compositions that match the object and nature of the criminal infraction can be considered related. Assuming the structure of offences and administrative offences, it might be concluded that adjacency can only speak with total or partial coincidence of the object and the objective side, because the subject composition of administrative offences may be broader solely because of the administrative delicacy of legal persons, which entails differences in the forms of the guilt of a legal (where the form of guilt is objectified by the legislator) and individuals. The very wording of adjacency of compositions looks in this sense to be a very conditional construction, differentiating compositions by consequences of illegal actions or omissions. The subject in determining adjacency is secondary, as is the subjective side, although they are necessary for the qualification of the act, but not the adjacency of the corpus. Adjacency supposes objective similarities and sometimes similarities of subjective elements. In the analyzed area, the adjacency is most clearly seen in the so-called "narcotic" components of crimes and administrative offenses. In this sense, as related there can be considered, for example, the regulations of Art. 6.16.1 of the Administrative Code and 228.3 of the Criminal Code, the difference between the objective side which only in the amount purchased, stored or transported precursors of narcotic drugs or psychotropic substances. If we are analyzing the adjacency of corpora of Articles 6.16 Administrative Code and 228.1 of the Criminal Code, then with all the identity of all the elements of the composition, they will vary only by the subject. Special attention is given to the provisions of Articles 6.20 of the Administrative Code and part 2 of Art. 242 of the Criminal Code on the responsibility for the dissemination to minors of pornographic materials. Although these provisions formally are not related to medical activities, 
they are of a medical nature in the sense they are related to protecting the health of minors.

The factual exception to Administrative Code rules on illegal medical activity is a special formulation that allows us to consider adjacency in relation to this particular object only in terms of Art. 235 of the Criminal Code and Articles 6.2 and Part 2 of Art. 14.1 the Administrative Code (Yakushima \& Huskova 2016: 23). Actually, the definitions themselves require public relations in the field of folk medicine. Comparative analysis of Articles 2 and 50 of Federal Law No. 323-FZ at 21.11.2011 (ed. at 06.03.2019) "On the basics of protecting the health of citizens of the Russian Federation" states that folk medicine, as is the case with medical care in general, is aimed at restoring health. A certain difference exists only in the methods of recovery, which are evaluated by the legislator through the category of "people's experience" without fixing the forms of such people's experience. It is obvious that excluding the occult-magical and religious rites from the methods of folk medicine, the legislator does not automatically recognize them as methods of healing. Regarding cases subject to administrative responsibility directly under Art. 6.2 of the Administrative Code, and indirectly associated with traditional medicine, certain articles of the Administrative Code, for example Art. 14.3, describes in detail the methods of alternative medical interventions: righting the ossified tongue, the learning of therapeutic poems, etc. ${ }^{14}$ While these kinds of non-traditional medical methods certainly warrant a high degree of skepticism, since the legislator recognizes some methods as therapeutic and others non-therapeutic, the most general grouping of methods of folk medicine will not be superfluous in medical legislation.

The most important issues of judicial practice that arise in cases related to the implementation of alternative methods of treatment are those pertaining to the relation of general and special norms of the Administrative Code. This is evidenced by rulings made by the Russian Supreme Court, which has explained that the responsibility for not having a license for performing traditional medical activities constitutes not only a specific violation of licensing terms, but also qualifies for the special rule set forth in Art. 6.2 of the Administrative Code as opposed to the

\footnotetext{
${ }^{14}$ Resolution of the Federal Antimonopoly service of Russia dated 20. 07. 2016 in case no. 4-14.3-759/00-08-16 http://solutions.fas.gov.ru (accessed 30 May 2019.
} 
provisions contained in Art. 14.1 of the Code ${ }^{15}$. In addition, the norms of the Administrative Code stipulating responsibility in advertising correlate with Art. 24 of the Federal law dated at 13.03.2006 № 38-FZ (as amended on 01.05.2019) "On advertising"16, which laid down certain limits for advertising of traditional methods of medicine.

It is important to understand that Art. 6.2 of the Administrative Code of the Russian Federation ${ }^{17}$ governs a special case of medical activity, and for the qualification of such activity in accordance with Art. 235 of the Russian Criminal Code, it is necessary to establish the consequences of causing harm by negligence to human health. State guarantees to patients receiving folk medicine are provided by monitoring the legality of folk medicine and establishing in Art. 6.2 of the Administrative Code for illegal practice of folk medicine.

Next, we shall analyze the construction of Art. 236 of the Criminal Code and Articles 6.4, 6.5, 6.6, and 6.7 of the Administrative Code. Art. 236 of the Criminal Code, in terms of this ratio, looks like a general corpus as it speaks in terms of a violation of sanitary and epidemiological rules in general, regardless of the object of sanitary protection. And of course, in relation to Art. 236 of the Criminal Code, adverse health consequences in the form of mass illness, poisoning or death are significant, provided that the cause-effect ratio is direct. Articles 6.4-6.7 of the Administrative Code are differentiated depending upon the object of the sanitary protection. The Criminal Code delineates the regulations while the Administrative Code sets forth the requirements towards protective activities. This might seem to be a formal difference, but it is not so. The specific sanitary requirements are set forth in the socalled Sanpins (sanitary norms and rules), which in fact comprise the regulations. Thus, these regulations of the Administrative Code exactly correlate with the provisions of Articles 23-28 of the Federal law "On sanitary and epidemiological welfare of the population"18. In other words, requirements are laid down by the

\footnotetext{
${ }^{15}$ On some issues that arise in courts when applying the Special part of the Code of Administrative offences of the Russian Federation: Resolution of the Plenum of the Supreme Court of the Russian Federation of 24. 10. 2006 No. 18 (ed. from 09. 02. 2012) - Bulletin of the Supreme Court of the Russian Federation, 2006. No. 12.

${ }_{16}$ Collection of legislation of the Russian Federation, 2006, no. 12, Art. 1232; http:www.pravo.gov.ru - (accessed 1 May 2019).

17 As per Art. 6.2 of the Administrative Code of the Russian Federation, "Engagement in folk-medicine (healing) in defiance of the procedure established by law - shall entail the imposition of an administrative fine in the amount of one thousand five hundred to two thousand roubles;

https://www.wipo.int/edocs/lexdocs/laws/en/ru/ru073en.pdf - (accessed 8 October 2020)/

18 http://www.pravo.gov.ru (accessed 26 July 2019).
} 
regulations, and in the context under study, these concepts should be recognized correlating as general (regulations) and particular (requirements). Accordingly, the Administrative Code refers to such direct objects of administrative and legal sanitary protection as: requirements for the operation of premises and buildings, structures, transport; requirements for drinking water; requirements for human nutrition; and, requirements for the recreation, education and training of children. For the fiscal purposes of the Federal Administrative Code, this construction is quite understandable.

Art. 6.3 of the Administrative Code acts as the general regulation in relation to Articles 6.4-6.7 of the Administrative Code and, accordingly, may be deemed to be related to Art. 236 of the Criminal Code along with Articles 6.4-6.7, which are special corpus.

Not all formulations of the Criminal Code and the Administrative Code, as they pertain to human health, can be assigned to compounds in the field of medical practice. Further, the aforesaid formulations also refer to the issue of improving the structure of the Code denominations of the heads of special units and the designation of compounds regarding human health within the sphere of medical practice. Also of interest is the structure proposed by Epifanova in Chapter 25 of the Criminal Code "Crimes against population health" in which the author combines the elements of crimes caused by "drugs" (Art. 228 of the Criminal Code) to the "Production and introduction into circulation of feed, medicine for animals, harmful to human health" (Epifanova, 2019a: 30)". Epifanova also assumes that it is necessary to introduce into the Criminal Code the corpus that will help prevent the acts that cause danger to human health. However, this is to be done in stages (Epifanova, 2019b: 2: 28).

In general, a scientist guided by the experience of the Western European countries is more apt to introduce both administrative and criminal legislation structures from the objective side. The consequence of this is that it then becomes difficult to link the wrongful act with the illegal consequences. An example of this phenomena is the articles of legislation of foreign countries (Switzerland, Serbia, South Korea) on liability for the use of prohibited veterinary drugs, feed, herbicides and other chemicals. The problem is that science at the domestic level is not always able establish the causal link or connection between the use of such products and their 
harmful effects on people and the environment. It is assumed that the knowledge of biological sciences and medicine in some foreign countries is at such a level that these kinds of connections can be drawn. We believe that this approach should be balanced in terms of medical science proving negative health consequences depending on the systematic use of low-quality water, products using GMOs, and antibiotics for animals used for human consumption.

These proposals should be taken into consideration by the legislator when developing a new Administrative Code and amendments to the Criminal Code in terms of related crimes and administrative offenses, not only in the field of medical activity, but also more broadly, in the sphere of human health protection.

\subsection{Criminal-legal control over the activities of legal entities in the field of health protection: world experience and Russian reality}

Holding legal entities criminally responsible for their behavior has deep historical roots. One of the earliest interpretations of the notion of a legal entity was given by Pope Innocent IV, who in 1245 wrote that a legal entity exists in concept only, since it does not have a will. Only members of the corporation can act, but not the corporation itself. Because the corporation cannot commit a crime, it cannot be excommunicated from the Church. Completely opposite concepts were held by Friedrich Karl Savigny in the middle of the 19th century. His theory forms the basis of modern French criminal law.

At the international level, the European Committee on crime problems of the Council of Europe recommended the recognition of legal persons as subjects of criminal liability for environmental crimes. The text of the explanatory memorandum to the recommendations of the Council of Europe in paragraph 20 states that some European countries have adopted different principles of criminal liability for legal entities. It should be borne in mind that at the international level, the issue of criminal liability of legal entities has been discussed many times. Thus, the International Congress on Criminal Law, which met in Bucharest in 1929, spoke in favor of the introduction of criminal liability for legal entities. The lawmakers of the Anglo-Saxon system of law did not see the problem of restoring such responsibility, but in continental Europe, the recognition of legal entities as subjects of criminal law met with serious obstacles related to the foundations of classical 
criminal law of the Romano-German system. Currently, legal entities are subject to criminal responsibility both in the countries of the Anglo-Saxon, continental, Muslim, socialist, and other legal systems. Facilitated by international legislation, the list of countries that subject legal entities to criminal responsibility is constantly expanding.

Currently, the issue of imposing criminal liability upon legal entities for the production of substandard food products, various medicines and biologically active supplements, the supply of poor-quality drinking water, the provision of services lacking adequate quality that negatively affects the health of consumers is becoming more acute. This issue is critically important in connection with a large number of persons whose rights in the field of health protection are or may be violated may be violated. In the pursuit of profit, and in an effort to increase the number of products produced, manufacturers often sacrifice quality and/or use technology without fully studying how certain substances (for example, preservatives, products of genetically modified engineering, etc.) can adversely affect human health. The consumer is not able to understand the quality of goods and services himself. Regulatory authorities often "do not keep up" with manufacturers and sometimes stand in a corrupt relationship with them. Manufacturers and suppliers of imports, in the pursuit of profit, lobby legislators to protect their immediate interests. To help curb such abuses and better protect the consuming public, Russian criminal law should provide for the liability of legal entities.

Federal law of November 21, 2011 N 323-FZ "On bases of health protection of citizens in the Russian Federation" stipulated a multidimensional concept of health as "a state of physical, mental as well as social well-being of a person, in which any diseases and disorders of functions of organs and systems of the body are absent." Meanwhile, the state guarantees the protection of citizens' health (Art. 2). Health protection is represented as a system of measures of political, economic, legal, social, scientific, medical, including sanitary and anti-epidemic (preventive) nature, carried out by state authorities of the Russian Federation, state authorities of the subjects of the Russian Federation, local governments, organizations, their officials and other persons, and citizens for the purpose of preventing diseases, preserving and strengthening the physical and mental health of each person, helping each person live an active life, and providing all citizens with medical care. Thus, it is confirmed that health protection includes not only direct medical care, but also the creation of a favorable 
environment in which a person can maintain their health for a long time. Health is presented as a capacious multidimensional concept that includes not only providing highquality medical care to citizens, but also creating a quality and healthy environment; growing and producing environmentally healthy food; producing high-quality animal feed, whose meat will later be consumed by humans; using environmentally friendly fertilizers for growing food grains, vegetables and fruits (including prolonged-acting fertilizers); producing and selling medicines that do not harm human health; creating an optimal health insurance system, etc. This expansive understanding of health allows us to reformulate the content of the chapter of the Criminal Code in a more constructive way by introducing new formulations that better meet the requirements of the time. However, now civil and administrative responsibility also play critical roles. It seems to us relevant to expand the interpretation of the concept of public health and the introduction of criminal liability of legal entities for crimes against public health (especially when adverse factors have a prolonged effect on the human body and the final damage to health is not immediately visible). Criminal liability is necessary because the norms of administrative law, due to the insignificance of administrative responsibility of legal entities, cannot alone cope with violations in the field of health protection.

Next, we will analyze the current foreign experience, which allows us to identify several areas related to the protection of citizens' health.

The Criminal Code of the People's Republic of China (adopted at the 5th session of the national people's Congress of the sixth convocation on March 14,1997) provides for the responsibility not only of individuals and officials, but also organizations, for example, for the following corpus:

Art. 332 establishes responsibility for violations of border sanitary and epidemiological rules that cause the spread of infectious diseases or creates a serious threat of its spread. It also establishes the responsibility of individuals. Violations lead to penalties in the form of either fines and/or imprisonment for up to three years or short - term arrest. 
However, if the crime referred to in part one of Art. 332 is committed by an organization, penalties shall be applied to the organization, and the directly responsible heads of the organization and other persons directly responsible shall be punished in accordance with part one of this article.

Art. 334 provides for liability for the illegal collection and supply of blood or the manufacture or supply of blood products that do not meet state standards and which may harm human health. For individuals, punishment is in the form of imprisonment for up to five years or short-term arrest and a fine. The same acts that cause a serious threat to human health are punishable by imprisonment for a term of five to ten years and a fine; the same acts that lead to particularly serious consequences are punishable by imprisonment for a term of more than ten years or indefinite imprisonment, as well as by a fine or confiscation of property.

Organizations that have the permission of the governing state bodies to collect and supply blood or to manufacture and supply blood products, but that carry out testing and research that is not in accordance with the rules or that violate other technological standards that have led to harm to human health, are fined, and the directly responsible heads of the organization and other persons who are directly responsible are punished by imprisonment for up to five years or short-term arrest.

For violation of the law on quarantine supervision of animals and plants transported across the border, evasion of quarantine supervision of animals and plants that caused a severe epidemiological situation, individuals are punished by imprisonment for up to three years or short-term arrest, as well as simultaneously or as an independent punishment, a fine.

The same crime committed by an organization results in the imposition of penalties not only to the organization, but also to the directly responsible heads of the organization and other persons directly responsible. Punishment consists of imprisonment for up to three years or short-term arrest, as well as simultaneously or as an independent punishment, by a fine.

Thus, the high risk of public danger, concern for the health of the population, and the protection of the sanitary and epidemiological situation, resulted in the need to establish criminal liability of legal entities as an independent subject of crime. 
In Japan, criminal liability is provided for legal entities that have committed violations in the field of plant protection (Art. VIII "Criminal provisions" of the law on plant protection No. 151 of May 4, 1950), as well as the field of plant quarantine (in accordance with Art. 39 of the law on plant quarantine No. 201 of June 06, 1951). Punishment consists of fines.

Section Six, Chapter XVIII, Art. 1071 of the Criminal Code of Georgia has established the criminal liability of legal entities, the types of punishments, and the procedure and conditions for their application. It states, in particular, that a legal entity may be held criminally liable for crimes provided for in the Criminal Code committed by the responsible person on behalf of or through (using) the legal entity or (and) in its favor. A legal entity may also be held criminally liable if the crime was committed on behalf of or through (using) the legal entity or (and) in its favor, regardless of whether the individual who committed the crime was identified. A legal entity shall also be held criminally liable if, due to improper supervision and control by the responsible person provided for in Part three of Art. 1071, it became possible for an individual subordinate to the legal entity to commit a crime in favor of the legal entity. It is important to note that criminal liability does not exempt a legal entity from the obligation to compensate victims for their damages caused by a crime, as well as the application of other liability measures established in relation to it by law. Art. 1073 establishes a wide list of types of penalties that may be imposed on legal entities: a) liquidation; b) deprivation of the right to engage in activities; c) fines; d) deprivation of property.

Of interest is the actual content of Art. 2891 "Violation of the rules of activity in the use of living genetically modified organisms", which sets out the following grounds for bringing legal entities to criminal responsibility: "1. Violation of the safety conditions for transporting live genetically modified organisms that caused barm to buman health or (and) serious consequences for the environment and biodiversity; 2. The use of live genetically modified organisms in a closed system without a corresponding license, resulting in harm to human health or (and) serious consequences for the environment and biodiversity; 3. Introduction of living genetically modified organisms into the environment that caused harm to human health or (and) severe consequences for the environment and biodiversity. A legal entity shall be punished for the acts provided for in this article by a fine or liquidation, or by deprivation of the right to engage in activities and a fine". 
Legal entities associated with individuals are recognized as subjects of crimes in the criminal legislation of several foreign countries. For example, Art. 121 of the Criminal Code of France of 1992, first established the liability of legal persons ${ }^{19}$, consolidated criminal liability to all legal persons, except the state. The criminal liability of legal entities does not exculpate individuals who are the perpetrator or accomplice in the commission of the same actions. The criminal liability of legal entities is dependent upon the presence of two circumstances: first, the criminal act must be solely benefit the legal entity, its manager or representative; second, criminal liability arises only in cases specifically provided for by law or regulation. Criminal liability is provided for a wide range of criminal acts, including, for example, intentional and unintentional attacks on life, attacks on the integrity of a person, acts directly endangering the life of another, and conducting experiments on people, among other types of crimes. The French Criminal Code provides for the liability of a legal entity not only for a completed act committed in its favor by its manager or its representative, but also for an attempt by these persons to commit a defined criminal act. In other words, criminal liability exists not only for the performance or co-performance by individuals, but also for participation: organizing, aiding and abetting.

In the said Criminal Code of France, Art. 131.39 possible types of punishment include the termination of a legal person (clause 1), the prohibition to exercise, directly or indirectly, one or more public professional activities definitively or for a period not more than five years (clause 2), the placement under judicial supervision for a maximum of five years (clause 3 ), the closure of all institutions, or one or more of the institutions of entrepreneurship (clause 4), with the exception of the fate (clause 5), the prohibition to appeal to the population with the purpose of placing deposits, or securities (clause 6).

The solution to the problems of criminal liability of legal entities in France is very instructive. It is essentially aimed at either limiting the activities of the entity for a specific period, usually up to five years, or terminating the legal entity.

\footnotetext{
${ }^{19}$ It should be noted that before this Code was in effect, certain laws established such responsibility, but they were not of a systematic nature.
} 
Under current American federal and state law, corporations under certain conditions may be criminally liable, along with individuals themselves. Federal law provides for many areas of activity where criminal liability is imposed directly on corporations, for example, the supply of products to consumers that are dangerous to life or health.

The criminal law of England also includes legal entities as subjects of crimes. For example, under English criminal law, a legal entity may be fined as a measure of criminal punishment.

We believe that in Russia, consistent with our comparative analysis, legal entities should be subject to criminal law for their criminal acts and/or omissions. In order to implement this, it is, of course, necessary to make appropriate amendments to the Criminal Code of the Russian Federation.

As we see the matter, a legal entity should bear criminal responsibility independently, not excluding the responsibility of any of its individual members, on the basis of the general grounds provided for in the Criminal Code. A legal entity should be held liable for both intentional and negligent crimes. The main types of punishment should be fines and liquidation of such legal entities with confiscation of property.

Physical and mental health, as non-material goods, are both objects of the subjective civil right to health. It is important to emphasize that both are not only personal rights but also a public good subject to legal regulation, security and protection.

Thus, according to clause two of Art. 8 of the Federal law of November 21, $2011 \mathrm{~N}$ 323-FZ "On bases of health protection of citizens in the Russian Federation" the right to health protection is provided by the environmental protection, creation of safe working conditions, favourable working conditions, life, rest, education and training of citizens, the production and sale of food of appropriate quality, quality, safe and affordable medicines, as well as providing affordable and quality medical care.

The right to health in an objective sense is comprised of a set of legal norms aimed at regulating, protecting and defending the physical and mental health of a person. 
The right to health in the subjective sense comprises the specific legal capacity of a citizen (an authorized subject) to demand that obligated persons observe, protect and defend their rights to physical and mental health.

Today, we can distinguish the following constituent elements comprising the right to health: 1) the right to medical care; 2) the right to donation and transplantation; 3) the right to participate in clinical testing; 4) the right to timely medical care, qualified and timely prosthetics, medical and cosmetological treatment.

More broadly, the right to health can be defined as a subjective, civil absolute right that belongs exclusively to authorized subjects-individuals (citizens), which has a personal, non-property and inalienable character, arising from a good devoid of economic content-health, and aimed at satisfying the interest (need) of the authorized person associated with the physical well-being of his person (Potapenko, 2019: 3).

Citizens often assert their right to health in civil proceedings due to medical errors occurring in the provision of medical care. According to paragraph two of Art. 779 of the Civil Code of the Russian Federation, medical services, along with others, can be provided on the basis of a contract for the provision of paid services. Considering disputes arising from this agreement, the courts usually recognize the consumer of medical services as being situated on the weak side of the relevant legal relationship (Gibadullina, 2015: 21). Consequently, in such disputes, including cases where medical services are provided to citizens on the basis of a contract of compulsory medical insurance, courts apply consumer protection legislation and regulations (Mateikovich, 2018: 39).

However, in case a citizen, for example, has not obtained highly-qualified medical care required, the obligation of causing harm to the health of such a patient begins to apply, resulting in applying civil liability to medical bodies.

In one case, the Supreme Court concluded that the death of a spouse caused by poor, unskilled care may be grounds for compensation of moral harm to the other spouse. ${ }^{20}$

\footnotetext{
${ }^{20}$ Definition of the Supreme Court of the Russian Federation N 86-KG18-11.
} 
Thus, it is obvious that in the case of a violation of the right of citizens to health, as a consequence of harm to the health of the patient, civil liability may be imposed, along with other forms of legal liability, upon the legal entities and individuals responsible for causing the harm.

Violations of citizens' right to health are, of course, not unique to Russia, but also occur in large numbers throughout Europe, where migration has become both a significant political and social problem. In particular, the commitment of European countries to ensure universal health coverage for all legal residents has faltered. One of the reasons for this situation is the numerous requests for medical assistance from migrants, including refugees.

For instance, one of the first health services to be reduced or completely discontinued was previously publicly funded health services related to migrants. In particular, in Spain, immigrants with infectious diseases are at a particular risk of losing access to certain health services (Kentikelenis, 2018: 61). In our view, this has affected the scale of the coronavirus pandemic in this country.

Swedish law entitles asylum-seekers to a voluntary health assessment and prompt medical treatment. However, this implies that there are restrictions on this right, and what the treatment may or may not include remains ultimately a decision for medical professionals in a particular case (Lobo Pacheco, Jonzon \& Hurtig, 2016: 19). Hence, Sweden's strategy in the fight against the COVID-19 pandemic.

Europeans are forced to defend their right to life and health in court. Thus, for example, the German Federal Court ${ }^{21}$ concluded that the plaintiff was physically unable to give birth to children naturally. However, the plaintiff could give birth using IVF in combination with ICSI. The insurance company refused to pay his expenses (17,500 euros), citing the increased risk of a miscarriage in his 44-year-old wife. Satisfying the claim, the court pointed out that attempts at artificial insemination are necessary medical treatment. Each attempt was estimated as having a $15 \%$ success rate, which is probably a sufficient possibility of a successful

\footnotetext{
${ }^{21}$ The aim of the German Federal court is to ensure the unity of judicial practice. It checks decisions of land, district and Supreme courts, mostly only for legal errors. Despite the fact that the decisions of the Federal court are formally binding only in certain cases, the courts of other instances actually follow its legal opinion almost without exception.
} 
pregnancy. The court noted that a married couple enjoys the right to such treatment in order to have children. ${ }^{22}$

These examples show that even in European countries, those who want to use the right to health to advocate universal health coverage must understand the strengths and weaknesses of this tool and advocate for specific measures rather than broad principles (Hammonds, 2018: 46). The human right to health should be used to influence global health policy in order to give greater attention to the interests of ordinary people.

Ultimately, health care around the world is severely under-resourced, and many national health budgets are well below recommended levels. The implementation of everyone's right to health depends to a large extent on the aforesaid.

\section{$3 \quad$ Results}

Thus, we can state that the Code of Administrative Judicial Procedure of the Russian Federation systematized the rules on the involuntary treatment of certain categories of patients. Certainly, the presence of a large number of non-codified norms in the system of medical legislation reduces the effectiveness of legal regulation of this type of public relations. Accordingly, fundamental tasks that must be undertaken include the codification of medical legislation, and the elimination of relations that directly affect the quality of medical care, its availability and timeliness (Amédée, 2011: 65). In terms of procedural legislation, a number of rules establishing lists of diseases when the mandatory judicial control is carried out during involuntary hospitalization remain at the sub legislative level.

\section{$4 \quad$ Conclusions and recommendations}

The factors that shall be taken into account when resolving cases of involuntary hospitalization in accordance with the Code of Administrative Judicial Procedure of the Russian Federation include: consideration of international health standards, multilevel and diverse system of sources of Russian law in the field of medical

\footnotetext{
22 See: http://juris.bundesgerichtshof.de/cgi$\mathrm{bin} /$ rechtsprechung/document.py?Gericht $=$ bgh\&Art $=$ en\&nr $=102539 \&$ pos $=0 \& a n z=1$ (accessed at $25 \mathrm{January}$ 2020).
} 
activity, the complexity of public relations, and formulating the subject of an administrative claim.

At the same time, in the medium term, Russia will be able to approach the European standards of procedural guarantees in involuntary hospitalization.

Despite the measures taken by the world community to localize the COVID 19 coronavirus pandemic, fundamental human and social rights should be correlated. The balance of personal and public interests in the sphere of health protection has a well-established border in the legislation of the Russian Federation, expressed by the phrase "poses a danger to one's self or others". Accordingly, the introduction of certain preventive measures should take place within the framework of the law, and not by-laws of Administrative acts, and the laws should have clearly defined material and legal grounds in the form of a legally fixed list of dangerous infectious diseases.

\section{Acknowledgments}

Acknowledgment: we express our gratitude to the Russian Fundamental Research Fund for financial support of our Project No. 18-011-00135

\section{References}

Kentikelenis, A. (2018) Intersecting crises: migration, the economy and the right to health in Europe. European Journal of Public Health, 28(suppl 5), pp. 61-62, doi: 10.1093/eurpub/cky224.

Amédée A. (2011) Code Médical: Ou, Recueil Des Lois, Decrets Et Reglements Sur L'étude L'enseignement Et L'exercice De La Médecine Civile Et Militaire En France (French Edition) (Paris: Nabu Press).

Baklushina, E. K. \& Bursikova D. V. (2016) K voprosu ob otvetstvennosti za nezakonnyu chastnyu medicinskyu praktiky (Revisiting Responsibility for Unlawful Private Medical Practice) (in Russian), Medicinskoe-pravo, (3), pp. 23-27.

Burashnikova, N. A. (2018) Sudebnoe sankcionirovanie nedobrovolnogo okazania medicincrji pomochi $\mathrm{v}$ Rossiskoi Federasii (Judicial authorization of involuntary medical care in the Russian Federation), Precedents of the European Court of Human Rights, [NO1] (3), pp. 11-17.

Epifanova, E. V. (2019a) Otdelnie aspekti ugolovnoi otvetstvennosti v sfere ochrani zdorovia gragdan (Certain aspects of criminal liability for crimes in the sphere of health protection of citizens), Legal Bulletin of the Kuban State University, (1), pp. 27-32.

Epifanova, E. V. (2019b) Prestupleniya protiv zdorovia grajdan: vlianie norm mejdunarodnich aktov na formirovane rossiiskogo ugolovnogo prava (Crimes against the health of citizens: the impact of norms of international acts on the formation of Russian criminal law), Legal Bulletin of the Kuban State University, (2), pp. 46-47.

Gibadullina L. T. (2015) Pacient kak slabaya storona v obiazatelstvach po okazanyu medicinskich uslug (The patient as a weak point in the obligation to provide medical services), Medical law, (3), pp 19-24.

Glushchenko A. N. A. (2016) Administrativno pravovoe regulirovanie ochrani zdorovia gragdan Rossiiskoi Federasii (Administrative and legal regulation of citizens' health protection in the Russian 
Federation), Thesis on competition of a scientific degree of candidate of legal sciences. Voronezh.

Gostin, Lawrence O. (2019) The Lancet Commission on Global Health Law: The Transformative Power of Law to Advance the Right to Health, The Journal of Global Health Science, 1(1), retrieved from: https://ssrn.com/abstract=3401003 (10 September 2020)

Hammonds, R; (2018) The Human Right to Health and Global Health Politics, In: McInnes, C.; Lee, K.; \& Youde, J., (eds.) The Oxford Handbook of Global Health Politics (Oxford University Press), DOI: 10.1093/oxfordhb/9780190456818.013.30.

Kontsevaya, A.V., Drapkina O. M., Balanova, U. A., Imayeva, A.E, Suvorova, E. I. \& Khudyakov, M. B. (2018) Ekonomicheskiy ucherb ot serdechno sosudistich zabolevaniy v Rossiiskoy Federasii v 2016 gody (Economic damage from cardiovascular diseases in the Russian Federation in 2016), Rational pharmacotherapy in cardiology, (2), pp.156-165.

Kulakova, V. Yu (2017) O nekotopich problemach pravovogo regulirovanya proizvodstva po delam o gospitalizacii grajdanina $\mathrm{v}$ medisinckyu protivotuberkuleznyu organizaciu (On the issues of legal regulation of proceedings on involuntary hospitalization of a citizen in the medical antituberculosis organization), Federal Laws: Experience, Analysis, Practice, (9), pp. 21-28.

Lebedeva, O.O (2015) Ispolzovanie individualnich administrativno-predupreditelnich mer rkak nezavisimoe administrativnoe proizvodstvo $\mathrm{v}$ structure administrativnogo prosessa (The use of individual coercive measures of administrative prevention as an independent administrative proceeding in the structure of the administrative process), Leningrad Law Journal, (3), pp. 203210.

Lobo Pacheco, L., Jonzon, R., \& Hurtig, A. K. (2016) Health Assessment and the Right to Health in Sweden: Asylum Seekers' Perspectives. PLOS ONE, 11(9), e0161842, doi: 10.1371/journal.pone.0161842.

Maleina, M. N. (2014) Uridicheskaya charakterictika zdorovia kak nematrialnogo blaga (Legal characteristics of health as an intangible good), Medical law, (4), pp. 12-16.

Mateikovich, M. S. (2018) Medisinskaya pomoch, medisinskiye uslugi I prava potrebiteley (Medical care, medical services and consumer rights), Judge, (2), pp. 38-41.-.

Mustafina-Bredikhina, D. M. (2018) Administrativno-pravovoe regulirovanie gosudarstvennogo kontrolia obiazatelnich trebovaniy, prediavliaemich k. kachestvu medisinckoy deiatelnostiv Rossii (Administrative and legal regulation of the state control of mandatory requirements for the quality of medical activities in Russia), abstract of the thesis of the candidate of legal sciences (Moscow).

Ponomarev, N. S. (2018) Reforma zdravoochraneniy v kontekste zachiti prav pazientov (Healthcare Reform in the context of patient rights protection), Medical law, (6), pp. 30 - 35.

Potapenko, S. V. (2019) Lichniye neimuchestvennyr prava na jizn I zdorovie (Personal non-property rights to life and health), Kuban Agency of judicial information PRO-SUD-123.RU: Legal network electronic scientific journal, 2(9). pp. 80-81, retrieved from: https://pro-sud123.ru/journals/2019/02/07_Potapenko_sv. pdf (4.1.2020).

Spakovsky H. \& Park J. (2011) Judicial Nullification in Georgia: Overriding Medical Malpractice Reform and Federal Law to Reward the Trial Bar, Legal Memorandum, (62), pp. 1-8.

Suchkova, T. E. (2012) K voprosu o predostavlenii vrachu ststusa doljnostnogo litsa (On the issue of granting a physician the status of an official), Bulletin of the Vyatka State University, (4), pp. 142145.

Suhrcke M, Rocco L., McKee M., Mazzuco M, Urban D. \& Steinherr, A. (2011) Economic consequences of non-infectious diseases and traumas in the Russian, retrieved from: http://www.euro.who.int/_data/assets/pdf_file/0006/74742/E89992R.pdf (9 September 2020).

Wendelboe, A., \& Andrade, et al. (2011) Importance of employee vaccination against influenza in preventing cases in long-term care facilities, Infection Control and Hospital Epidemiology; 32(10), pp. 990-997, doi: 10.1086/661916.

Yaroshenko K. B. (1990) Jizn I zdorovie pod zachitoi zakona. Grajdansko-pravovaya zachita lichnich neimychestvennich prav grajdan (Life and health under the protection of law. Civil law protection of personal non-property rights of citizens) (Moscow: Legal literature). 